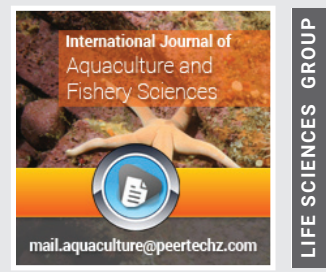

\section{A Survey on Fish Population Availability in Different Season in Northern India}

\author{
Shikha Gomra', Sunaina Chandel ${ }^{1}$, Atif Zargar ${ }^{1}$ and Arup \\ Giri ${ }^{1,2 *}$
}

'Department of Life Science, School of Basic Sciences, Arni University, H.P, India

${ }^{2}$ Animal Biotechnology Laboratory, DRDO-Defence Institute of High Altitude Research (DIHAR), Chandigarh, India
Received: 11 February, 2020

Accepted: 17 April, 2020

Published: 18 April, 2020

*Corresponding author: Dr. Arup Giri, ICMR-Senior Research Fellow, Animal Biotechnology Laboratory, DRDO-Defence Institute of High Altitude Research (DIHAR), Chandigarh-160002, India, Tel: +91-9646919386; E-mail: arupsatadal@gmail.com

Keywords: Fish species; Himachal Pradesh; Jammu; Market survey; Punjab

https://www.peertechz.com

Check for updates

\begin{abstract}
Among all the animal protein sources, fish is the best dietary animal protein source due to the presence of less saturated fat and readily available in the market. A survey on fish availability in the fish market has pasteurized the seasonal availability of the different species of fishes. The Present study conducted on the availability of different fish species during the summer, spring, and winter months at the Gummat fish market, Jammu Division; Bilaspur fish market, Himachal Pradesh; Amritsar fish market, Punjab. The survey result showed that in all the fish markets, the price of the fish was higher in the winter season than in the summer season. Mainly Labeo rohita, Tor mosal, Catla catla, Wallago attu, Bramidae, Anabas testudineus, Carassiusauratus, Catla catla, Ctenophoryngodon idella, Labeo rohita, Lethrinus bohar, Nandus nandus, Pampus chinensis, Pangasius buchanani, Platycephalus fuscus, Rita rita, Solea solea, Sperata seenghala, Telopia nilotica, Tenualosa ilish were found in these markets throughout the season. In the case of body weight and body length of different fish species, it has been found that bodyweight greatly varied in the summer and winter months. Lower availability and insufficient body weight of different fish species in the winter month affects the income of fish sellers of this market. From this study, it might be concluded that variable price, the low body weight of fish species may affect the income of fish sellers in this market. A special lookout should have to be taken by the state fisheries department so that the continuous fish supply may take place in this market.
\end{abstract}

\section{Introduction}

The fisheries segment recognized as a powerful income generator as, on the one hand, it stimulates the growth of several minor industries and, on the other hand, provides cheap and nutritious food. It plays a vital role in the socio-economic life of thousands of people directly or indirectly involved in it, as it allows for a source of occupation and income to millions of rural farmers, particularly women [1-3]. A well-developed fish marketing system intimately depends upon the fish production and the developed fishery sector with a proper setup of economy and substructure [4]. In the case of saline/brackish water fishery, India has a long marine coastline $(7,517 \mathrm{~km})$, a vast number of fishing villages (3,827 nos), and has a good amount of traditional fish landing centers (1,914 nos). However, in freshwater fishery, India has excellent freshwater resources in terms of freshwater rivers and canals $(195,210 \mathrm{~km})$, minor and significant reservoirs (2.9 million hectares (Mha), ponds and lakes (2.4 Mha), and has flooded plain wetlands and water bodies (0.8 Mha) [5]. After the independence fisheries sector has seen massive 11 -fold increment, i.e., from 0.75 million tonnes (1950-51) to 9.6 million tonnes (2012-13), which resulted in a supreme average annual growth rate of $4.5 \%$ over the years. India is the second-largest country in worldwide fish production and is home to more than $10 \%$ of the global fish diversity. However, the commercial fish farming rate is going to higher in India. The demand for fish and the consumption rate is increasing gradually. It has an urgent requirement for the fish market development in the rural part of India [6-7].

Some of the studies indicated that Himachal Pradesh has the great potency for the trout fishing (Oncorhynchus mykiss, Salmo trutta fario, Schizothorax richardsonii, Schizothorax richardsonii) near the various stints of Beas, Satluj, and Ravi River. This region is also characterized with the presence of Mahseer, Carps and Hill stream fishes [8]. The Punjab, another state in northern India, has different types of fishes like Clarias batrachus, Wallago attu, Mystus cavasius, M. bleekeri, Rita rita, Sperata seenghala, Sperata aor, Oncorhyncus mykiss and 
many other food as well as ornamental fishes [9-11]. One study from Jammu and Kashmir, one UT in north India, reported the presence of Trout (Oncorhynchus mykiss), Mirror carp (Cyprinus carpio specularis) and Country fish (Schizothoracine species) [12].

After several studies on the fish farm cultivation in several countries, it is indicating that fish far cultivation may enhance the socioeconomic of the country. For this process, a welldeveloped strategy should have to take in a long-term way. The study on the fish market can analyze the status of the availability of different fish species throughout the season. The availability of the fish is an excellent protein source for the daily lifestyle of human civilization that depends upon the fish. The study area which has been covered for this project work was the entirely untouched area for this study. In this context, this work has been taken to survey the fish species available in the market throughout the year.

\section{Materials and methods}

\section{Study Area}

Gummat fish market, Jammu Division The first survey site was the Gummat market, which is present in Jammu, India. The survey site was presented in Figure 1. This market has both wholesale and trade shops. This study was carried out for three months of 2018-2019 (August, October, and February). In the Gummat market, there were four retail shops and three both retail and wholesale companies. The survey was conducted in the morning session and collected all the information about fish marketing. As per the report, there were five primary natural sources of fishes (Chenab, Tawi, Ravi, Basantar, and Ujh River).
The information regarding cultivated species, rate production, availability, marketing channel, transport facilities, etc. were collected from the fish traders of this market.

Bilaspur fish market, Himachal Pradesh Second survey site was the Bilaspur market located in Bilaspur district, Himachal Pradesh, India. The survey site was presented in Figure 2. The primary fish market near the Diyra sector, which has both a wholesale and retail market. The study was carried out for a period of 5 months, from August to February 2018. In this market, there were only five shops, per day supply 18qu fish to each shop. The fish market was surveyed around 11:00 am to 3:00 pm during every visit. We collected information about cultivated species, rate production, availability, marketing channel, transport facilities, cost of marketing consumer behavior and problems of the market from fish traders. Crosscheck interview was conducted with vital information such as local leaders. Local fish traders were middlemen who harvested fish at point sites and dispose of those directly to retailers or through commission agents.

Amritsar fish market, Punjab The third survey site was the Amritsar fish market, Amritsar, Punjab, India. The survey site was presented in Figure 3. The main fish market of Amritsar is also known as Old Mewa Mandi of Amritsar (Hall Gate fish market). The study was carried out for a period of 5 months from September 2018 to January 2019. In the Amritsar market, there were only seven shops, per day supply 20 Qu. Fish to each shop. The fish market was surveyed around $12 \mathrm{pm}$ to 4 pm during every visit. We have collected information about cultivated species, rate production, availability, marketing channel, transport facilities, cost of marketing consumer behavior and problems of the market from fish traders.

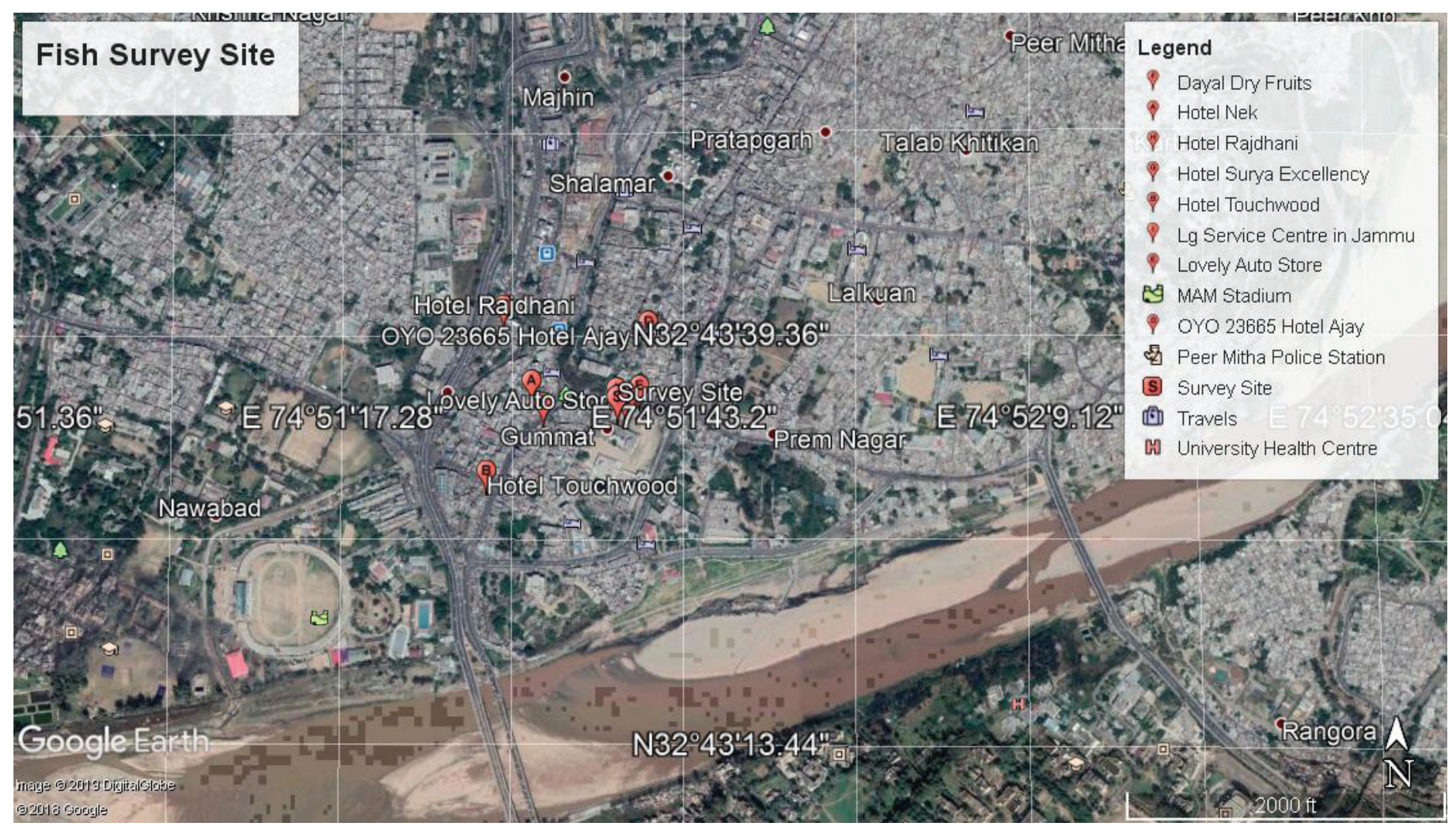

Figure 1: Site of the fish survey at Gummat Fish Market, Jammu, India, prepared by Google 3D Earth Software.

Citation: Gomra S, Chandel S, Zargar A, Giri A (2020) A Survey on Fish Population Availability in Different Season in Northern India. Int J Aquac Fish Sci 6(2): 015-020. DOI: https://dx.doi.org/10.17352/2455-8400.000051 


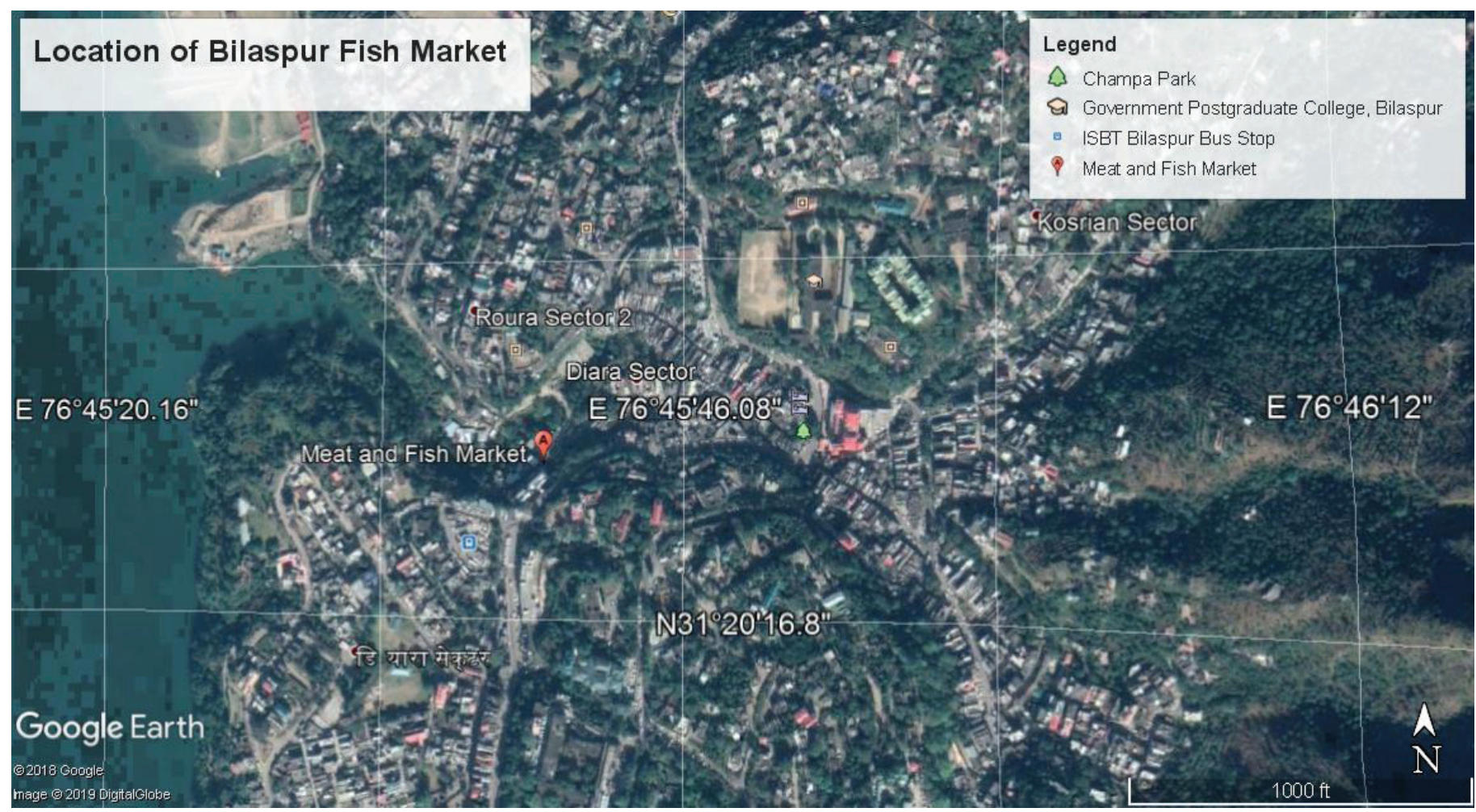

Figure 2: Site of the fish survey at Bilaspur Fish Market, Himachal Pradesh, India, prepared by Google 3D Earth Software.

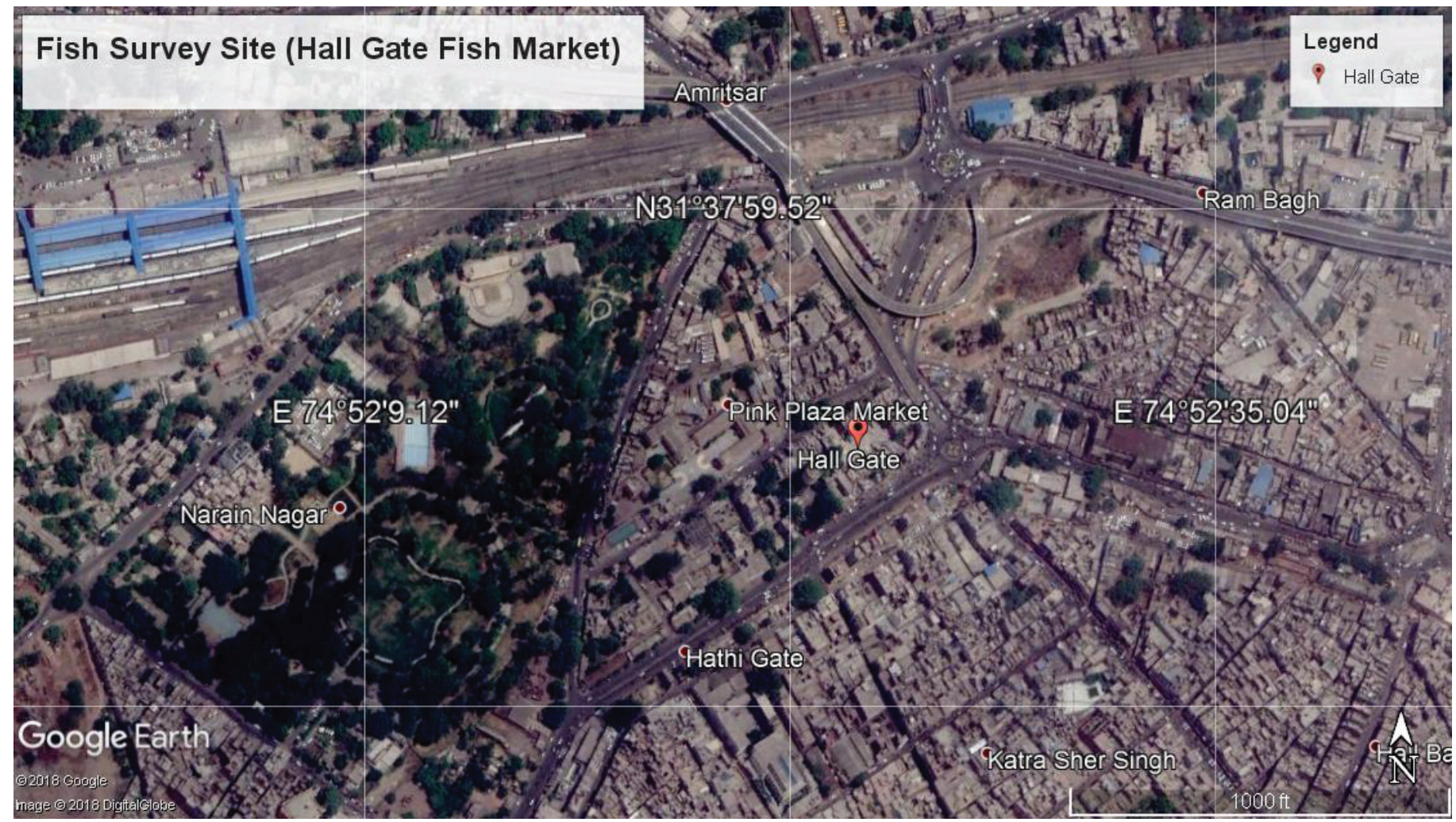

Figure 3: Site of the fish survey at Amritsar Fish Market, Punjab, India, prepared by Google 3D Earth Software.

\section{Selected Parameters}

The Total number of fish species found during the survey is six. The study was carried out for different periods. The fish length was measured by measuring tape. The weighing machine measured fish weight. Fish price during survey fish, sellers give all the information about the fish price of every species. 
The income of fish sellers During the survey, it has been found that the per day sale of fishes was Rs 10000-12000, with a profit of 2000 during the summer season but decreases in the winter season.

\section{Results and Discussion}

\section{Gummat fish market, Jammu Division}

In the fish market of Gummat in the Jammu division, three retailers and two wholesale shops were present. About six species have been observed in this market on local demand. Fish species like Catla catla, Labeo rohita, Tor mosal, Wallago attu, and Bramidae were found in the Gummat market during the survey.

The price of fishes varies a little bit in this market in the summer and winter months. The availability of fish species also varies except for Rahu, Malli, and Mahaseer. The price of fishes like Labeo rohita, Tor mosal, and Wallago attu has a fixed rate in August and October months. Still, it increases in February due to the lower availability of fishes. The cost of Catla catla has almost set rates in all months. In the winter price of nearly all species is the same and increases up to Rs $200 / \mathrm{kg}$. In August and October months, the cost of Labeo rohita, Tor morsal, and Wallago attu were Rs $170 / \mathrm{kg}$, and in February, it goes on up to Rs 200/kg. Bramidae is found only in the summer season, and it cost up to Rs $200 / \mathrm{kg}$. Whereas, Catla catla was available in all the three months and cost up to Rs 200/kg (Table 1).

During the survey, we found that August's month was the most populated. Some fishes were found in August month but was absent in other months while some species were found in all months. Body length and body weight was varied due to seasonal changes. The changes might be due to the less availability of food materials for fishes in the nursery pond in the winter season. It might be also due to the very low temperature in winter months as the temperature affects the basic metabolic rate in the fish [13].

\section{Bilaspur fish market, Himachal Pradesh}

In the fish market of Bilaspur, only five fish shops were present. About 61 fish species observed in our study, which belongs to 13 families. In the survey area, two types of fish were found like Grade A and Grade B type fish depending upon the local populace demand. Labeo rohita, Catla catla, Sperata seenghala belong in the Grade A fish category and Hypophthalmichthys molitrix, Tor tambroides, Cyprinus carpio, Anguilla sp, Seriola hippos, Ctenopharyngodon idella Cirrhinus cirrhosus, Hypophthhalmichthys nibilis were belong in the Grade B fish category. The gradation system already has been decided by the local fish market authority depending upon the consumption rate and price of a particular fish.

The price of the fish has been fixed in this market throughout the season except for August. In this month, Labeo rohita, Catla catla, Mystus seenghala were sold for 150 Rs./kg and Cirrhinus cirrhosus, Ctenopharyngodon idella, Cyprinus carpio, Hypophthalmichthys molirix, Hypophthalmichthys nobilis, Seriola hippos, Tor tambroides were sold for 120 Rs./kg (Table 3).
But, Cirrhinus cirrhosus, Ctenopharyngodon idella, Cyprinus carpio, Hypophthalmichthys molirix, Hypophthalmichthys nobilis, Seriola hippos, Tor tambroides has a fixed price in other months that is $150 \mathrm{Rs} / \mathrm{kg}$ (Table 3).

August month was the most fish populated month, but in other months, the number of fish species was less. Cirrhinus cirrhosus was only found in August and February. Hypophthalmichthys nobilis was only found in August. Whereas, Catla catla was available only in August and October. October is the only month when Labeo rohita was did not found. The availability of all the fish in different months depicting that summer month has a higher availability of fish species than the winter month.

In the case of body weight and body length of different fish species, it has been found that bodyweight greatly varied in the summer and winter months (Table 4). Bodyweight of Labeo rohita in August was $15 \mathrm{~kg}$, whereas, in the winter month, February, it was only $0.5 \mathrm{~kg}$ (Table 4). It might be due to the very low temperature in the winter month as the temperature affecting the basic metabolic rate in the fish and unavailability of sufficient food [13].

Lower availability and insufficient body weight of different fish species in the winter month affects the income of fish sellers of this market. Summer month has a higher availability of fish species and higher body weight (Table 4). It was reflected by the income of the fish seller, which is about 10 Lakhs. But, this amount of income went in decrease pattern like in September income was 8 Lakhs, on October 7 Lakhs, on November 5 Lakhs, and in February, income was 4.5 Lakhs.

Table 1: Price details of different fish species in different months available at Gummat fish market, Jammu, India.

\begin{tabular}{|c|c|c|c|c|c|}
\hline \multicolumn{2}{|c|}{ August 2018} & \multicolumn{2}{|c|}{ October 2018} & \multicolumn{2}{|c|}{ February 2019} \\
\hline Fish Name & $\begin{array}{c}\text { Price (Rs./ } \\
\text { kg) }\end{array}$ & Fish Name & $\begin{array}{c}\text { Price (Rs./ } \\
\text { kg) }\end{array}$ & Fish Name & $\begin{array}{c}\text { Price (Rs./ } \\
\text { kg) }\end{array}$ \\
\hline Labeo rohita & 170 & Labeo rohita & 170 & Labeo rohita & 200 \\
\hline Tor mosal & 170 & Tor mosal & 170 & Tor mosal & 200 \\
\hline Catla catla & 200 & Catla catla & 200 & Catla catla & 200 \\
\hline Wallago attu & 170 & Wallago attu & 170 & Wallago attu & 200 \\
\hline Bramidae & 200 & & & & \\
\hline
\end{tabular}

Table 2: Bodyweight and Body length of different fish species in different months available at Gummat fish market, Jammu, India.

\begin{tabular}{|c|c|c|c|c|c|c|c|c|}
\hline \multicolumn{3}{|c|}{ August 2018} & \multicolumn{3}{|c|}{ October 2018} & \multicolumn{3}{|c|}{ February 2019} \\
\hline $\begin{array}{c}\text { Fish } \\
\text { Name }\end{array}$ & $\begin{array}{l}\text { Body } \\
\text { length } \\
(\mathrm{cm})\end{array}$ & $\begin{array}{c}\text { Body } \\
\text { weight } \\
(\mathrm{kg})\end{array}$ & $\begin{array}{c}\text { Fish } \\
\text { Name }\end{array}$ & $\begin{array}{c}\text { Body } \\
\text { length } \\
\text { (cm) }\end{array}$ & $\begin{array}{c}\text { Body } \\
\text { weight } \\
(\mathbf{k g})\end{array}$ & $\begin{array}{c}\text { Fish } \\
\text { Name }\end{array}$ & $\begin{array}{l}\text { Body } \\
\text { length } \\
\text { (cm) }\end{array}$ & $\begin{array}{c}\text { Bodyweight } \\
\text { (kg) }\end{array}$ \\
\hline $\begin{array}{l}\text { Labeo } \\
\text { rohita }\end{array}$ & 40 & 1.50 & $\begin{array}{l}\text { Labeo } \\
\text { rohita }\end{array}$ & 27 & 0.80 & $\begin{array}{l}\text { Labeo } \\
\text { rohita }\end{array}$ & 15 & 0.30 \\
\hline Tor mosal & 42 & 0.90 & $\begin{array}{c}\text { Tor } \\
\text { mosal }\end{array}$ & 28 & 0.60 & $\begin{array}{c}\text { Tor } \\
\text { mosal }\end{array}$ & 16 & 0.30 \\
\hline Catla catla & 40 & 1.50 & $\begin{array}{l}\text { Catla } \\
\text { catla }\end{array}$ & 22 & 0.50 & $\begin{array}{l}\text { Catla } \\
\text { catla }\end{array}$ & 12 & 0.25 \\
\hline $\begin{array}{c}\text { Wallago } \\
\text { attu }\end{array}$ & 30 & 1.20 & $\begin{array}{c}\text { Wallago } \\
\text { attu }\end{array}$ & 20 & 0.65 & $\begin{array}{c}\text { Wallago } \\
\text { attu }\end{array}$ & 14 & 0.30 \\
\hline Bramidae & 42 & 1.25 & & & & & & \\
\hline
\end{tabular}

Citation: Gomra S, Chandel S, Zargar A, Giri A (2020) A Survey on Fish Population Availability in Different Season in Northern India. Int J Aquac Fish Sci 6(2): 015-020. DOI: https://dx.doi.org/10.17352/2455-8400.000051 
Table 3: Price details of different fish species in different months of 2018 and 2019 available at Bilaspur fish market, Himachal Pradesh, India.

\begin{tabular}{|c|c|c|c|c|c|c|c|c|c|}
\hline \multicolumn{2}{|l|}{ August 2018} & \multicolumn{2}{|c|}{ September 2018} & \multicolumn{2}{|c|}{ October 2018} & \multicolumn{2}{|c|}{ November 2018} & \multicolumn{2}{|c|}{ February 2019} \\
\hline Fish Name & $\begin{array}{l}\text { Price } \\
\text { (Rs) }\end{array}$ & Fish Name & $\begin{array}{l}\text { Price } \\
\text { (Rs.) }\end{array}$ & Fish Name & Price (Rs.) & Fish Name & Price (Rs.) & Fish Name & Price (Rs.) \\
\hline Labeo rohita & 150 & Labeo rohita & 150 & Mystus seenghala & 150 & Mystus seenghala & 150 & Labeo rohita & 150 \\
\hline Catla catla & 150 & Catla catla & 150 & Tor tambroides & 150 & Tor tambroides & 150 & Mystus seenghala & 150 \\
\hline Mystus seenghala & 150 & Mystus seenghala & 150 & Cyprinus carpio & 150 & Cyprinus carpio & 150 & Cirrhinus cirrhosus & 150 \\
\hline $\begin{array}{c}\text { Hypophthalmichthys } \\
\text { molirix }\end{array}$ & 120 & $\begin{array}{c}\text { Hypophthalmichthys } \\
\text { molirix }\end{array}$ & 150 & Seriola hippos & 150 & Seriola hippos & 150 & $\begin{array}{c}\text { Hypophthalmichthys } \\
\text { molirix }\end{array}$ & 150 \\
\hline Tor tambroides & 120 & Tor tambroides & 150 & $\begin{array}{c}\text { Hypophthalmichthys } \\
\text { molirix }\end{array}$ & 150 & $\begin{array}{l}\text { Hypophthalmichthys } \\
\text { molirix }\end{array}$ & 150 & Tor tambroides & 150 \\
\hline Cyprinus carpio & 120 & Cyprinus carpio & 150 & & & Labeo rohita & 150 & Cyprinus carpio & 150 \\
\hline Seriola hippos & 120 & Seriola hippos & 150 & & & & & Seriola hippos & 150 \\
\hline $\begin{array}{l}\text { Ctenopharyngodon } \\
\text { idella }\end{array}$ & 120 & & & & & & & & \\
\hline Cirrhinus cirrhosus & 120 & & & & & & & & \\
\hline $\begin{array}{c}\text { Hypophthalmichthys } \\
\text { nobilis }\end{array}$ & 120 & & & & & & & & \\
\hline
\end{tabular}

Table 4: Bodyweight and Body length of different fish species in different months of 2018 and 2019 available at Bilaspur fish market, Himachal Pradesh, India.

\begin{tabular}{|c|c|c|c|c|c|c|c|c|c|c|c|c|c|c|}
\hline \multicolumn{3}{|c|}{ August 2018} & \multicolumn{3}{|c|}{ September 2018} & \multicolumn{3}{|c|}{ October 2018} & \multicolumn{3}{|c|}{ November 2018} & \multicolumn{3}{|c|}{ February 2019} \\
\hline Fish Name & $\begin{array}{c}\text { Body } \\
\text { weight } \\
(\mathbf{k g})\end{array}$ & $\begin{array}{l}\text { Body } \\
\text { length } \\
(\mathrm{cm})\end{array}$ & Fish Name & $\begin{array}{c}\text { Body } \\
\text { weight } \\
(\mathrm{kg})\end{array}$ & $\begin{array}{l}\text { Body } \\
\text { length } \\
\text { (cm) }\end{array}$ & Fish Name & $\begin{array}{c}\text { Body } \\
\text { weight } \\
(\mathrm{kg})\end{array}$ & $\begin{array}{l}\text { Body } \\
\text { length } \\
(\mathrm{cm})\end{array}$ & Fish Name & $\begin{array}{c}\text { Body } \\
\text { weight } \\
(\mathrm{kg})\end{array}$ & $\begin{array}{l}\text { Body } \\
\text { length } \\
(\mathrm{cm})\end{array}$ & Fish Name & \begin{tabular}{|c|} 
Body \\
weight \\
$(\mathrm{kg})$
\end{tabular} & $\begin{array}{l}\text { Body } \\
\text { length } \\
(\mathrm{cm})\end{array}$ \\
\hline Labeo rohita & 15.00 & 40 & Labeo rohita & 2.50 & 14 & $\begin{array}{c}\text { Mystus } \\
\text { seenghala }\end{array}$ & 2.00 & 10 & Mystus seenghala & 2.00 & 14 & Labeo rohita & 0.50 & 12 \\
\hline Catla & 5.00 & 24 & Catla & 3.00 & 15 & Tor tambroides & 1.00 & 8 & Tor tambroides & 1.00 & 8 & Mystus seenghala & 0.50 & 15 \\
\hline Mystus seenghala & 3.00 & 18 & $\begin{array}{c}\text { Mystus } \\
\text { seenghala }\end{array}$ & 3.00 & 18 & Cyprinus carpio & 2.00 & 8 & Cyprinus carpio & 2.00 & 8 & Cirrhinus cirrhosus & 0.50 & 11 \\
\hline $\begin{array}{c}\text { Hypophth } \\
\text { almichthys molirix }\end{array}$ & 13.00 & 36 & $\begin{array}{l}\text { Hypophth } \\
\text { almichthys } \\
\text { molirix }\end{array}$ & 6.00 & 17 & Seriola hippos & 1.50 & 18 & Seriola hippos & 1.00 & 14 & $\begin{array}{c}\text { Hypophth } \\
\text { almichthys molirix }\end{array}$ & 3.50 & 26 \\
\hline Tor tambroides & 8.00 & 29 & Tor tambroides & 1.00 & 8 & $\begin{array}{l}\text { Hypophth } \\
\text { almichthys } \\
\text { molirix }\end{array}$ & 3.00 & 23 & $\begin{array}{c}\text { Hypophth } \\
\text { almichthys molirix }\end{array}$ & 2.50 & 19 & Tor tambroides & 4.00 & 26 \\
\hline Cyprinus carpio & 4.00 & 16 & Cyprinus carpio & 2.00 & 8 & & & & Labeo rohita & 0.50 & 12 & Cyprinus carpio & 1.00 & 15 \\
\hline Seriola hippos & 3.50 & 26 & Seriola hippos & 1.50 & 19 & & & & & & & Seriola hippos & 0.30 & 12 \\
\hline $\begin{array}{l}\text { Ctenopharyngodon } \\
\text { idella }\end{array}$ & 5.00 & 28 & & & & & & & & & & & & \\
\hline Cirrhinus cirrhosus & 1.00 & 10 & & & & & & & & & & & & \\
\hline $\begin{array}{c}\text { Hypophth } \\
\text { almichthys nobilis }\end{array}$ & 16.00 & 40 & & & & & & & & & & & & \\
\hline
\end{tabular}

\section{Amritsar fish market, Punjab}

Only seven fish shops were present, in the fish market of Amritsar. About 18 fish species recorded which belongs to ten families. In the survey area, eighteen types of fishes which were graded as A, B, C, D, and E depending upon the local population demand. In grade A, Labeo rohita, Pangasius buchanani, Platycephalus fuscus, and Sperata seenghala were types of fishes found in September 2018. In grade B, Catla catla, Anabas testudineus, and Carassius auratus were types of fishes found in October 2018. In grade C, Telapia nilotica, Solea solea, Platycephalus fuscus, and Ctenophoryngodon idella were types of fishes found in November 2018. In grade D, Pampus chinensis, Tenualosa ilisha, Rita rita, and Lethrinus bohar were types of fishes found in December 2018. In grade E, Labeo rohita, Nandus nandus, Catla catla, and Sperata seenghala were types of fishes found in January 2019 (Table 5). The price of all the fishes was varied greatly in every month. The sizes and body weight of all the fishes were significantly larger in the summer season than in the winter season (Tables 5,6).

\section{Conclusions}

The study was performed using conventional survey techniques for the availability of different fish species in different time intervals, price of fish species in different months, monthly income of fish sellers, and sources of fish in this market. The conventional technique did bodyweight and body length of the available fish. The availability and bodyweight of the different fish were varied during different months. Most fish species and large size fish was found in the summer month. High income earned by the fish seller in the summer month. Therefore, it might be concluded that there was a lack of fish production in the winter months. Hence, an 
Table 5: Bodyweight and Body length of different fish species in different months of 2018 and 2019 available at the Amritsar fish market, Punjab, India.

\begin{tabular}{|c|c|c|c|c|c|c|c|c|c|c|c|c|c|c|}
\hline \multicolumn{3}{|c|}{ September 2018} & \multicolumn{3}{|c|}{ October 2018} & \multicolumn{3}{|c|}{ November 2018} & \multicolumn{3}{|c|}{ December 2018} & \multicolumn{3}{|c|}{ January 2019} \\
\hline Fish Name & $\begin{array}{c}\text { Body } \\
\text { weight }(\mathrm{kg})\end{array}$ & $\begin{array}{c}\text { Body } \\
\text { length } \\
(\mathrm{cm})\end{array}$ & Fish Name & $\begin{array}{l}\text { Body } \\
\text { weight } \\
\text { (kg) }\end{array}$ & $\begin{array}{c}\text { Body } \\
\text { length } \\
(\mathrm{cm})\end{array}$ & Fish Name & $\begin{array}{c}\text { Body } \\
\text { weight } \\
(\mathrm{kg})\end{array}$ & $\begin{array}{l}\text { Body } \\
\text { length } \\
(\mathrm{cm})\end{array}$ & Fish Name & $\begin{array}{c}\text { Body } \\
\text { weight } \\
(\mathrm{kg})\end{array}$ & $\begin{array}{l}\text { Body } \\
\text { length } \\
\text { (cm) }\end{array}$ & Fish Name & $\begin{array}{c}\text { Body } \\
\text { weight } \\
(\mathrm{kg})\end{array}$ & $\begin{array}{l}\text { Body } \\
\text { length } \\
\text { (cm) }\end{array}$ \\
\hline Labeo rohita & 0.60 & 35 & Catla catla & 6.00 & 67 & Telapia nilotica & 0.50 & 14 & $\begin{array}{l}\text { Pampus } \\
\text { chinensis }\end{array}$ & 0.15 & 33 & $\begin{array}{l}\text { Labeo } \\
\text { rohita }\end{array}$ & 0.25 & 25 \\
\hline $\begin{array}{l}\text { Pangasius } \\
\text { buchanani }\end{array}$ & 1.00 & 43 & $\begin{array}{l}\text { Anabas } \\
\text { testudineus }\end{array}$ & 1.00 & 75 & Solea solea & 1.00 & 47 & $\begin{array}{c}\text { Tenualosa } \\
\text { ilisha }\end{array}$ & 1.00 & 48 & $\begin{array}{l}\text { Nandus } \\
\text { nandus }\end{array}$ & 2.00 & 17 \\
\hline $\begin{array}{l}\text { Platycephalus } \\
\text { fuscus }\end{array}$ & 0.20 & 62 & $\begin{array}{l}\text { Carassius } \\
\text { auratus }\end{array}$ & 0.80 & 37 & $\begin{array}{l}\text { Platycephalus } \\
\text { fuscus }\end{array}$ & 1.00 & 44 & Rita rita & 0.25 & 25 & Catla catla & 4.00 & 55 \\
\hline $\begin{array}{c}\text { Sperata } \\
\text { seenghala }\end{array}$ & 1.00 & 52 & Patra & 0.125 & 25 & $\begin{array}{c}\text { Ctenophoryngodon } \\
\text { idella }\end{array}$ & 0.80 & 35 & $\begin{array}{l}\text { Lethrinus } \\
\text { bohar }\end{array}$ & 3.00 & 20 & $\begin{array}{c}\text { Sperata } \\
\text { seenghala }\end{array}$ & 3.00 & 65 \\
\hline
\end{tabular}

Table 6: Price details of different fish species in different months of 2018 and 2019 available at the Amritsar fish market, Punjab, India.

\begin{tabular}{|c|c|c|c|c|c|c|c|c|c|}
\hline \multicolumn{2}{|c|}{ September 2018} & \multicolumn{2}{|c|}{ October 2018} & \multicolumn{2}{|c|}{ November 2018} & \multicolumn{2}{|c|}{ December 2018} & \multicolumn{2}{|c|}{ January 2019} \\
\hline Fish Name & $\begin{array}{c}\text { Price/kg } \\
\text { (Rs.) }\end{array}$ & Fish Name & $\begin{array}{c}\text { Price/kg } \\
\text { (Rs.) }\end{array}$ & Fish Name & Price/kg (Rs.) & Fish Name & Price/kg (Rs.) & Fish Name & Price/kg (Rs.) \\
\hline Labeo rohita & 160 & Catla catla & 200 & Telapia nilotica & 40 & $\begin{array}{l}\text { Pampus } \\
\text { chinensis }\end{array}$ & 150 & Labeo rohita & 160 \\
\hline $\begin{array}{l}\text { Pangasius } \\
\text { buchanani }\end{array}$ & 120 & $\begin{array}{c}\text { Anabas } \\
\text { testudineus }\end{array}$ & 240 & Solea solea & 400 & Tenualosa ilisha & 120 & Nandus nandus & 100 \\
\hline $\begin{array}{l}\text { Platycephalus } \\
\text { fuscus }\end{array}$ & 250 & Carassius auratus & 160 & Platycephalus fuscus & 250 & Rita rita & 160 & Catla catla & 200 \\
\hline Sperata seenghala & 330 & Patra & 80 & $\begin{array}{l}\text { Ctenophoryngodon } \\
\text { idella }\end{array}$ & 160 & Lethrinus bohar & 140 & Sperata seenghala & 330 \\
\hline
\end{tabular}

alternative way should have to apply for the higher production of fish in the winter month. Future research can be carried out by considering all the factors which influence the fish supply chain to all this fish market.

\section{Acknowledgments}

The authors are highly thankful to all the fish sellers of three different markets for providing information about fishes and their co-operation during the study.

\section{Author contribution}

First, second, and third authors contributed equally to survey the fish market from a different region of northern India. They are equally contributed to the manuscript preparation, also. The fourth author supervised the whole study; data compiled, arranged, and edited the manuscript.

\section{References}

1. Welcomme RL, Cowx IG, Coates D, Béné C, Funge-Smith S, et al. (2010) Inland capture fisheries. Philosophical transactions of the Royal Society of London. Series B Biological Sciences 365: 2881-2896. Link: https://bit.ly/3euUe51

2. Lam VW, Cheung WW, Reygondeau G, Sumaila UR (2016) Projected change in global fisheries revenues under climate change. Sci Rep 6: 32607. Link: https://go.nature.com/3cnRODa

3. He L, Ding Z, Yin F, Wu M (2016) The impact of relative energy prices on industrial energy consumption in China: A consideration of inflation costs. SpringerPlus 5: 1001. Link: https://bit.ly/2KbqQmt

4. Chourey P, Meena D, Varma A, Saxena G (2014) Fish marketing system in Bhopal (M.P.). Biological Forum - An International Journal 6: 19-21.
5. Kumar BG, Datta KK, Joshi PK, Katiha PK, Suresh R, et al. (2008) Domestic fish marketing in India-changing structure, conduct, performance and policies. Agricultural Economics Research Review 21: 345-354. Link: https://bit.ly/2VEBJCl

6. Rajput RS, Pandey S, Bhadauria S (2017) Status of water pollution in relation to industrialization in Rajasthan. Rev Environ Health 32: 245-252. Link: https://bit.ly/2RMGGbi

7. Kurunthachalam SK (2013) Indian Waters: Past and Present. Hydrology: Current Research S10: 001. Link: https://bit.ly/3evJanc

8. Sharma I (2018) Status of trout fishes versus climate change in Himachal Pradesh, North Western Himalaya. Link: https://bit.ly/3cvcMjw

9. Sharma RK, Bhat RA (2015) Length-weight relationship, condition facto of rainbow trout (Oncorhynchus mykiss) from Kashmir waters. Annals of Biological Research 6: 25-29. Link: https://bit.ly/3etoqNL

10. Sarkar UK, Khan GE, Dabas A, Pathak AK, Mir JI, et al. (2013) Length-weight relationship and condition factor of selected freshwater species found in River Ganga, Gomti and Rapti, India. J Environ Biol 34: 951-956. Link: https://bit.ly/2RNYToW

11. Priyanka C, Tewari G, Hassan SS (2018) Study on biometric growth parameters in different fish species of family Bagridae from Harike wetland, Punjab India. J Entomol Zool Stud 6: 1667-1672. Link: https://bit.ly/2KecqBR

12. Qayoom I, ul Hassan Balkhi M, Ahmad B (2015) Change in Fishing Patterns in Jammu and Kashmir Provinces of $\mathrm{J}$ and K-A Comparative Study. Current World Environment 10: 179. Link: https://bit.ly/2KgYQxQ

13. O’Gorman EJ, Ólafsson ÓP, Demars BO, Friberg N, Guðbergsson G, et al. (2016) Temperature effects on fish production across a natural thermal gradient. Global Change Biology 22: 3206-3220. Link: https://bit.ly/3cmpHVO

Copyright: (@) 2020 Gomra S, et al. This is an open-access article distributed under the terms of the Creative Commons Attribution License, which permits unrestricted use, distribution, and reproduction in any medium, provided the original author and source are credited.

Citation: Gomra S, Chandel S, Zargar A, Giri A (2020) A Survey on Fish Population Availability in Different Season in Northern India. Int J Aquac Fish Sci 6(2): 015-020. DOI: https://dx.doi.org/10.17352/2455-8400.000051 